\title{
IMPACT OF VARIOUS LEVELS OF MEDICINAL PLANTS ON SOME PRODUCTIVE AND PHYSIOLOGICAL TRAITS IN BROILER CHICKENS
}

\author{
NeChiRVAn H. ARTOShI, IHSAn T.TAYBE* and BÜNYAMIN SÖĞÜT ${ }^{* *}$ \\ *Dept. of Animal Production, College of Agricultural engineering science, University of Duhok, \\ Kurdistan Region-Iraq \\ ${ }^{* *}$ Dept. of Animal Science, Faculty of Agriculture, Bingol University, Bingol, Turkey
}

(Accepted for Publication: October 21, 2019)

\begin{abstract}
A study aimed to evaluate the influence of using three medicinal plants on some productive and physiological traits of broiler chickens. Two hundred eighty-eight chicks (Ross 308) randomly distributed into eight groups with three replicates in each treatment. First group was fed the basal diet, without any plant supplement, as control group, while the $2^{\text {nd }}$ and $3^{\text {rd }}$ groups were fed the same diet with thyme $(5$ and $10 \mathrm{~g} / \mathrm{kg}$, respectively), the $4^{\text {th }}$ and $5^{\text {th }}$ groups were fed diets with Adiantum ( 3 and $5 \mathrm{~g} / \mathrm{kg}$, respectively) and the $6^{\text {th }}$ and $7^{\text {th }}$ groups were fed diets supplemented with rosemary at 5 and $10 \mathrm{~g} / \mathrm{kg}$, respectively, the combination of plants $(7.5 \mathrm{~g} / \mathrm{kg}$ of thyme and $7.5 \mathrm{~g} / \mathrm{kg}$ of rosemary and $4 \mathrm{~g} / \mathrm{kg}$ of adiantum) added to the basal diet of group $8^{\text {th }}$. The active compounds of the three plants were analyzed by Gas Chromatography/Mass Spectrometry. Live body weight was measured at weekly intervals. At the end of the experiment, the following traits were measured: carcass traits, internal organ, lymphoid organs and meat color. The obtained results summarized as follows: Fourteen, Fifteen and Twenty-one compounds were identified in the Thyme, Adiantum and Rosemary samples, respectively, and the major compounds were carvacrol $(60.77 \%)$, gamma-terpinene $(41.23 \%)$ and $\alpha$-Pinene $(51.87 \%)$, respectively. Overall, there is a significant effect of medicinal plants on live body weight in both genders, in which the male chicks in the $4^{\text {th }}$ group and female chicks in $7^{\text {th }}$ group had significantly higher live body weight. Regarding male chickens, T2, T3 and T8 groups have significantly higher carcass yield, also each of dressing percentage, breast, legs and wings were higher in T3 group. Furthermore, neck and back weight was higher in T3 group in both genders.

It can be concluded that the supplementation of medicinal plants to broiler's diet had a beneficial effect on most of broiler performance, particularly in male chickens that fed T3 group (Thyme $5 \mathrm{~g} / \mathrm{kg}$ ).
\end{abstract}

KEY WORDS: Thyme, Adiantum, Rosemary, Performance, Physiology, meat color, broiler. https://doi.org/10.26682/cajuod.2020.22.2.22

\section{INTRODUCTION}

$\mathbf{N}$ atural feed additives of plant origin are generally believed to be safer, healthier and less subject to hazards. Medicinal plants and their products are used in broiler diets or through drinking water in which their beneficial effects as phytogenic feed additives have been proven (Soltan et al. 2008 and Dalkiliç et al. 2009). Herbs have been identified to improvement antimicrobial, antiviral, and antioxidative activities and to sitmulate the immune and endocrine systems (Dahiya et al. 2006). Besides, scientists recently observed that the stimulating and appetizing activity of herbs and plant extracts on poultry digestive and immune system could be benefit health and performance of poultry farms (Gollnisch and Halle 2001; Tucker 2002b). Using medical plant including thyme, rosemary and adiantum in broiler diets could have many effects to broiler performance and health like as enhancing digestion system throughout stimulation of endogenous enzyme (Brugalli, 2003), having autoxidation properties, antimicrobial activities of due to their phytochemical components (Lee et al. 2004b; Dorman and Deans 2000). Thyme (Thymus Vulgaris) is one of the Lamiaceae family (Mikaili et al. 2010). Also it has used for many medicinal purposes: antimicrobial, antinociceptive, respiratory diseases and etc. (Demir et al. 2008). The main phenolic 
components in Thymus vulgaris are carvacrol and Thymol (Masada, 1976). Carvacrol and Thymol proved that can improve the digestion of nutrients also it has believed to exhibit a range of beneficial physiological effects (Cabuk et al. 2006). Adiantum capillus veneris is one of Adiantaceae Families and the most common species with potential importance for medicinal and nutritive purposes. Adiantum been used for medicinal due to their significant effects and traditionally used to treatment of many ailments for a long period (Husson et al. 1986; Ambusta 1986). Rosemary is one of the kingdom Plantae, family Lamiales and it belongs to two species in the genus Rosemarinus (Al-Kassie et al. 2011). Carnosal, epirosmanol, carnosic acid, caffeic acid and its derivatives such as rosmarinic acid are the most importance contain rosemary with a wide range of different phenolic compounds with biological activities (Cuvelier et al. 1996; Richheimer et al. 1996; Offord et al1997). Mona et al. (2010) and Al-Kassie et al. (2011) rosemary and their active compound is known have powerful antioxidant activity and thus a therapeutic potential in treating many disease conditions. Rosemary and they are contains mentioned by many author that improved performance of broiler (Basmacioğlu et al. (2004); Abd El-Latif et al. (2013); Souri et al. (2015). In many studies, the different active components of herbal plants reported the different influence on poultry performance, so the current study aimed to investigate the effects of different levels of herbs (thymus vulgaris, Adiantum capillus-veneris $L$ and Rosemarinus Officinalis) and their combination in the diet on Growth Performance, Physiological, meat color, Carcass traits of broiler chicken.

\section{MATERIAL AND METHOD}

The present study was carried out in Poultry Farm of Animal Science, Faculty of Agriculture at the University of Bingol, Bingol city $(1152 \mathrm{~m}$, $\left.38.886^{\circ} \mathrm{N}, 40.4978^{\circ} \mathrm{E}\right) /$ Turkey. A Total of 288-day old mixed sex broiler chicks were randomly distributed to eight treatments with three replicate of twelve chicks based on a completely randomized design. The ration was formulated to meet the nutrient requirements of chicks according to NRC (1994). The birds were fed with standard broiler starter (1 to 21 days) and finisher (22 to 42 days) rations throughout the experimental period as shown in Tables 1 and the ingredients and the chemical composition of the diets for experimental broiler starter and finisher diets. The thyme, adiantum and rosemary were obtained from Akery city, Duhok province, Kurdistan region, Iraq. It's above altitude $603 \mathrm{~m}, 36^{\circ} 43^{\prime} 60 \mathrm{~N}, 43^{\circ} 52^{\prime} 47 \mathrm{E}$. The plants were dried under room temperature and ground to fine powders by Retsch device. The active compounds of the three plants were analyzed by Gas Chromatography/Mass Spectrometry (GC/MS) in the central Bingol laboratory, University of Bingol. Fourteen compounds were identified in the Thyme (Thyme Kotshyanus) sample by GC-MS. The major compounds of this plant were carvacrol (60.77\%), p-cymene $(9.05 \%)$ and 2-amino-5nitrothizole $(5.77 \%)$ (Table 2) (Figure 1). Fifteen compounds were identified in the Adiantum (Adiantum capillus veneris) sample and gamma-terpinene $(41.23 \%)$ was the most abundant component, followed by phenol $(33.82 \%)$ and cis-piperitol, acetate $(8.78 \%)$ (Table 3) (Figure 2). Twenty-one compounds were detected in the Rosemary (Rosmarinus Officinalis) sample; the most compounds were $\alpha$-Pinene (51.87\%), Eucalyptol (31.63\%) and Camphor (5.88\%) (Table 4) (Figure 3). Live body weight was measured weekly throughout the experimental period by digital balance for all chicks (Naji 2006). At the end of the experiment (42 days), a sample of two random birds (male and female) from each replicate within treatment was slaughtered to determine the dressing percentage. Before the slaughtering, each bird was weighed and numbered and after that the birds were slaughtered, dressing, carcass, breast, legs, wings, back with neck, abdominal fat, visceral orange (liver, heart and gizzard), and lymphoid organs index (bursa of fabricious and spleen) percentages were then measured. Sample of breast was skin removed and then color parameters $\left(\mathrm{L}^{*}, \mathrm{a}^{*}, \mathrm{~b}^{*}\right)$ were measured using a colorimeter (Lovibond RT-Series 500). $\mathrm{L}^{*}=$ lightness; $\mathrm{a}^{*}=$ redness and $\mathrm{b}^{*}=$ yellowness (meat color), were measured of breast meat according to CIE system (CIE, 1976).

\section{Statistical Analysis}

The experiment executed as a complete randomized design (CRD), all data analyzed using the CRD (Completely Randomized Design) of (SAS 2002-2003). Duncan`s multiple 
range tests were used to compare differences among treatments means (Duncan, 1955).

The statistical model:

Yij $=\mu+t j+$ eij

Where:
Yij = represent the observation value which affected by ith treatment (feed supplement) that found with in jth replicate.

$\mu=$ general mean of population.

$\mathrm{ti}=$ represent the effect of ith treatment .

eij $=$ represent the experimental error.

Table (1): Percent of diets ingredient for experimental broiler starter and finisher diets and their calculated chemical analysis:

\begin{tabular}{|c|c|c|}
\hline Ingredient & Starter diet & Finisher diet \\
\hline Corn & 50 & 52 \\
\hline Wheat & 5 & 4 \\
\hline Barley & 3 & 4 \\
\hline Wheat bran & 5 & 5 \\
\hline Soybean meal & 32 & 28 \\
\hline vegetable oil & 2 & 3 \\
\hline Limistone & 1.5 & 2.05 \\
\hline Dicalcium phosphate & 0.8 & 0.8 \\
\hline DL methionine & 0.2 & 0.2 \\
\hline L- lysine & 0.2 & 0.2 \\
\hline Anti-fungul & 0.05 & 0.05 \\
\hline Salt & 0.2 & 0.2 \\
\hline vit. Primex & 0.5 & 0.5 \\
\hline Approximately Analysis & \multicolumn{2}{|c|}{ Chemical Composition } \\
\hline Crude protein & 21.76 & 18.88 \\
\hline Energy Kcal/kg & 2978.10 & 3027.60 \\
\hline Fat & 4.40 & 5.46 \\
\hline Linoleic acid & 2.18 & 2.71 \\
\hline Crude fiber & 3.17 & 3.15 \\
\hline Methionine & 0.58 & 0.56 \\
\hline Lysine & 1.40 & 1.28 \\
\hline Tryptophan & 0.35 & 0.32 \\
\hline Meth. + Cystine & 0.74 & 0.68 \\
\hline Threonine & 0.88 & 0.81 \\
\hline Arginine & 1.44 & 1.30 \\
\hline $\mathrm{Ca}$ & 0.93 & 1.14 \\
\hline $\mathrm{P}$ & 0.44 & 0.43 \\
\hline $\mathrm{Na}$ & 0.15 & 0.15 \\
\hline $\mathrm{Cl}$ & 0.18 & 0.18 \\
\hline
\end{tabular}


Table (2): The volatile compounds in Thyme (Thyme Kotshyanus) samples analyzed by GC-MS:

\begin{tabular}{ccclc}
\hline $\begin{array}{c}\text { Peak } \\
\text { no. }\end{array}$ & $\begin{array}{c}\text { RT } \\
\text { (mint) }\end{array}$ & $\begin{array}{c}\text { Area } \\
(\% \text { of total) }\end{array}$ & Identified Compound & Quality \\
\hline 1 & 15.494 & 1.96 & Pyrimidine & 38 \\
\hline 2 & 16.856 & 9.05 & P-Cymene & 95 \\
\hline 3 & 17.640 & 4.03 & Gamma-Terpinene & 94 \\
\hline 4 & 19.586 & 5.11 & Nonanal & 80 \\
\hline 5 & 20.198 & 0.94 & Unknown & 27 \\
\hline 6 & 24.369 & 0.68 & Lathosterol & 37 \\
\hline 7 & 26.349 & Carvacrol & 90 \\
\hline 8 & 28.266 & 2-Ethyl-5-Propylphenol & 49 \\
\hline 9 & 29.444 & 1.23 & Santolina Triene & 45 \\
\hline 10 & 32.483 & 3.15 & Dodecane & 59 \\
\hline 11 & 44.459 & 0.67 & 2-Amino-5-Nitrothiazole & 72 \\
\hline 12 & 46.118 & $\mathbf{5 . 7 7}$ & 2-Ethoxy-4,6-Dichloro-Symmtriazine & 38 \\
\hline 13 & 46.702 & 3.91 & Silane & 14 \\
\hline 14 & 48.785 & 1.24 & Acenaphthenedione & 50 \\
\hline
\end{tabular}

Table (3): The volatile compounds in Adiantum (Adiantum capillus veneris) samples analyzed by GC-MS:

\begin{tabular}{lllll}
\hline $\begin{array}{c}\text { Peak } \\
\text { no. }\end{array}$ & $\begin{array}{c}\text { RT } \\
\text { (mint) }\end{array}$ & $\begin{array}{c}\text { Area } \\
\text { \% of total) }\end{array}$ & Identified Compound & Quality \\
\hline 1 & 14.762 & 4.66 & Myrcene & 91 \\
\hline 2 & 15.884 & 0.30 & Alpha-Phellandrene & 93 \\
\hline 3 & 16.255 & 8.78 & Cis-Piperitol, Acetate & 56 \\
\hline 4 & 16.851 & 5.59 & 2-lsopropyltoluene & 86 \\
\hline 5 & 17.526 & 0.52 & Sabinene & 94 \\
\hline 6 & 17.978 & 41.23 & Gamma-Terpinene & 89 \\
\hline 7 & 18.687 & 0.47 & Terpinolene & 95 \\
\hline 8 & 19.105 & 0.23 & 3-Carene & 90 \\
\hline 9 & 19.620 & 0.66 & Dehydro-P-Cymene & 97 \\
\hline 10 & 22.481 & 0.21 & A-Terpinene & 90 \\
\hline 11 & 24.498 & Phenol & 93 \\
\hline 12 & 29.508 & 33.82 & Caryophyllene & 95 \\
\hline 13 & 30.200 & 2.44 & Valencene & 94 \\
\hline 14 & 30.446 & 0.24 & Unknown & 91 \\
\hline 15 & 54.627 & 0.41 & Ethyltetramethylcyclopentadiene & 89 \\
\hline
\end{tabular}

Table (4): The volatile compounds in Rosemary (Rosmarinus Officinalis) samples analyzed by GCMS:

\begin{tabular}{ccclc}
\hline $\begin{array}{c}\text { Peak } \\
\text { no. }\end{array}$ & $\begin{array}{c}\text { RT } \\
\text { (mint) }\end{array}$ & $\begin{array}{c}\text { Area } \\
\text { \% of total }\end{array}$ & identified Compound & Quality \\
\hline 1 & 17.989 & 51.87 & Alpha-Pinene & 96 \\
\hline 2 & 21.674 & 31.63 & Eucalyptol & 96 \\
\hline 3 & 22.367 & 0.60 & Gamma-Terpinene & 95 \\
\hline 4 & 23.294 & 0.33 & Terpinolene & 95 \\
\hline 5 & 24.112 & 0.64 & Nonanal & 90 \\
\hline 6 & 24.678 & 0.09 & Filifolone & 90 \\
\hline 7 & 27.019 & Camphor & 94 \\
\hline 8 & 27.368 & 5.88 & Isoborneol & 94 \\
\hline 9 & 27.980 & 2.86 & Alpha-Terpineol & 86 \\
\hline 10 & 28.970 & 1.09 & Unknown & 52 \\
\hline
\end{tabular}


Journal of University of Duhok.,Vol. 22, No.2(Agri. and Vet. Sciences),Pp 196-209, 2019(Special Issue) The $3^{\text {rd }}$ International Agricultural Conference, $2^{\text {nd }}-3^{\text {rd }}$ October 2019, Duhok

\begin{tabular}{lllll}
\hline 11 & 29.519 & 0.58 & Verbenone & 99 \\
\hline 12 & 29.742 & 0.37 & Trans-2-Tridecen-1-Ol & 90 \\
\hline 13 & 30.189 & Bornyl Acetate & 91 \\
\hline 14 & 31.161 & 0.33 & Sphingosine & 94 \\
\hline 15 & 31.716 & 0.21 & Carvacrol & 90 \\
\hline 16 & 32.237 & 0.06 & Unknown & 90 \\
\hline 17 & 32.746 & 0.68 & Copaene & 96 \\
\hline 18 & 32.998 & 0.08 & Trans-2-Octenal & 94 \\
\hline 19 & 33.988 & 0.37 & Hexane & 35 \\
\hline 20 & 34.778 & 0.10 & Beta-Caryophyllene & 99 \\
\hline 21 & 36.145 & 1.91 & Humulene (Alpha) & 98 \\
\hline
\end{tabular}

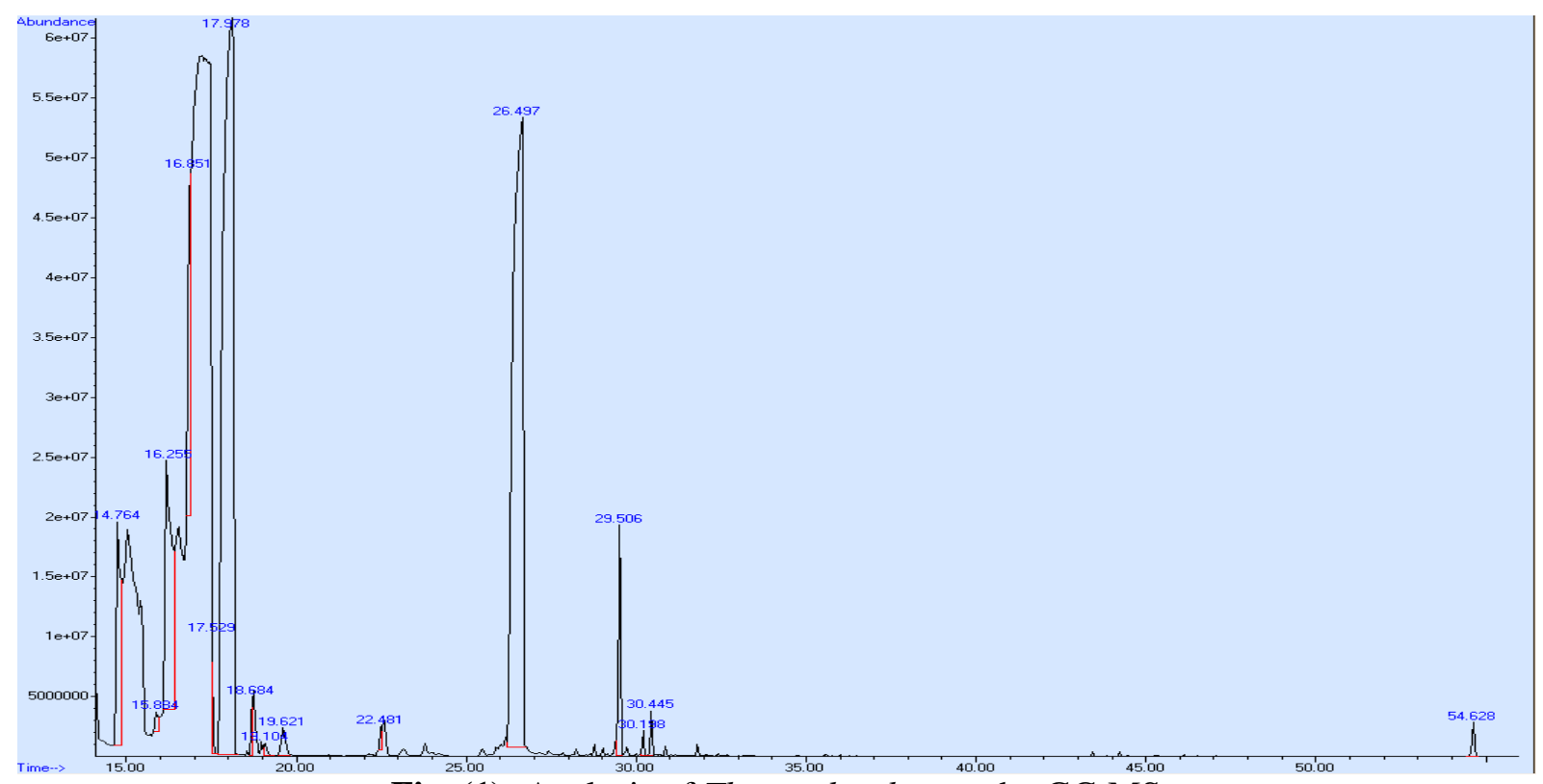

Fig. (1): Analysis of Thymus kotshyanus by GC-MS 


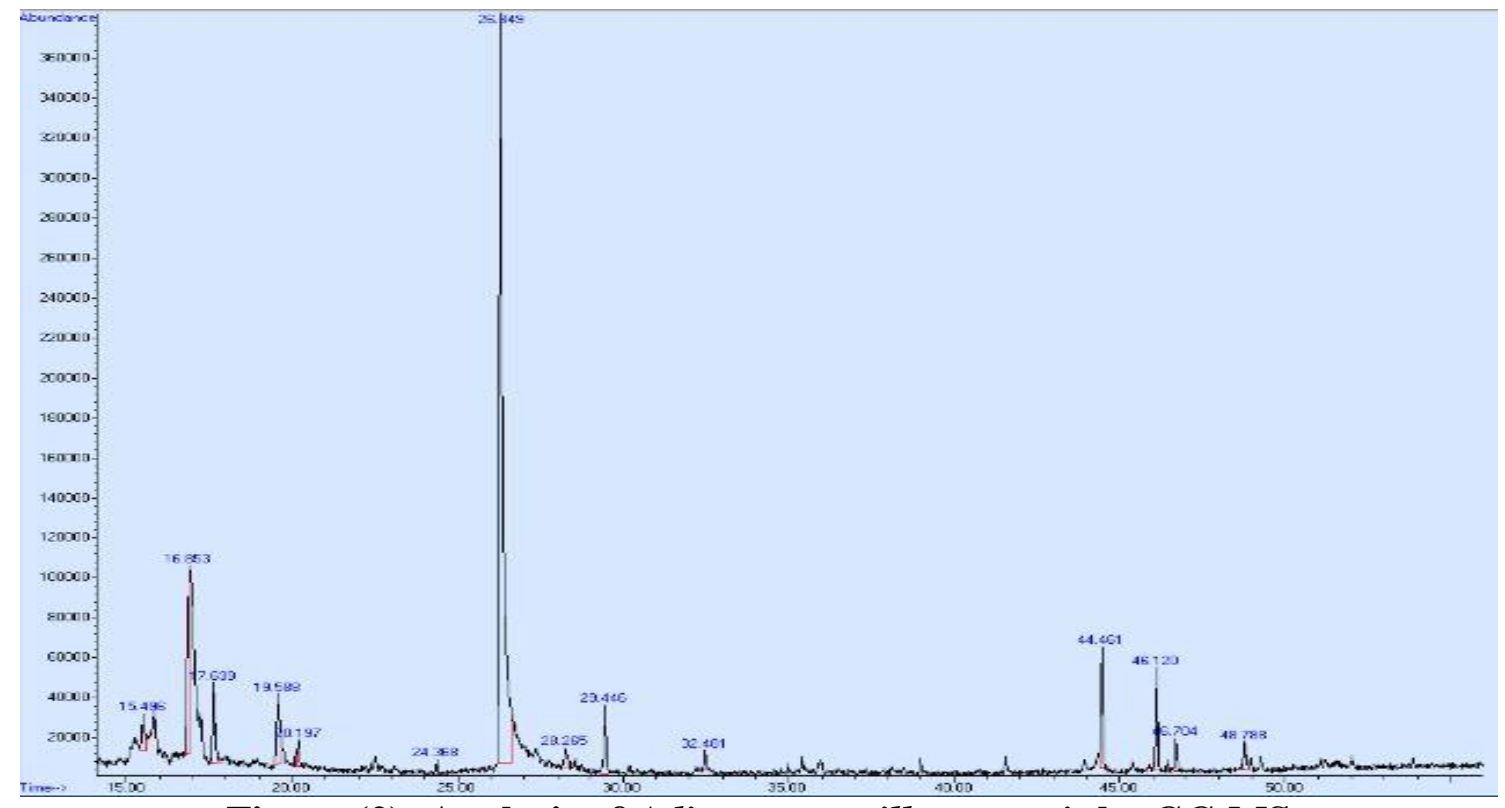

Figure (2): Analysis of Adiantum capillus-veneris by GC-MS

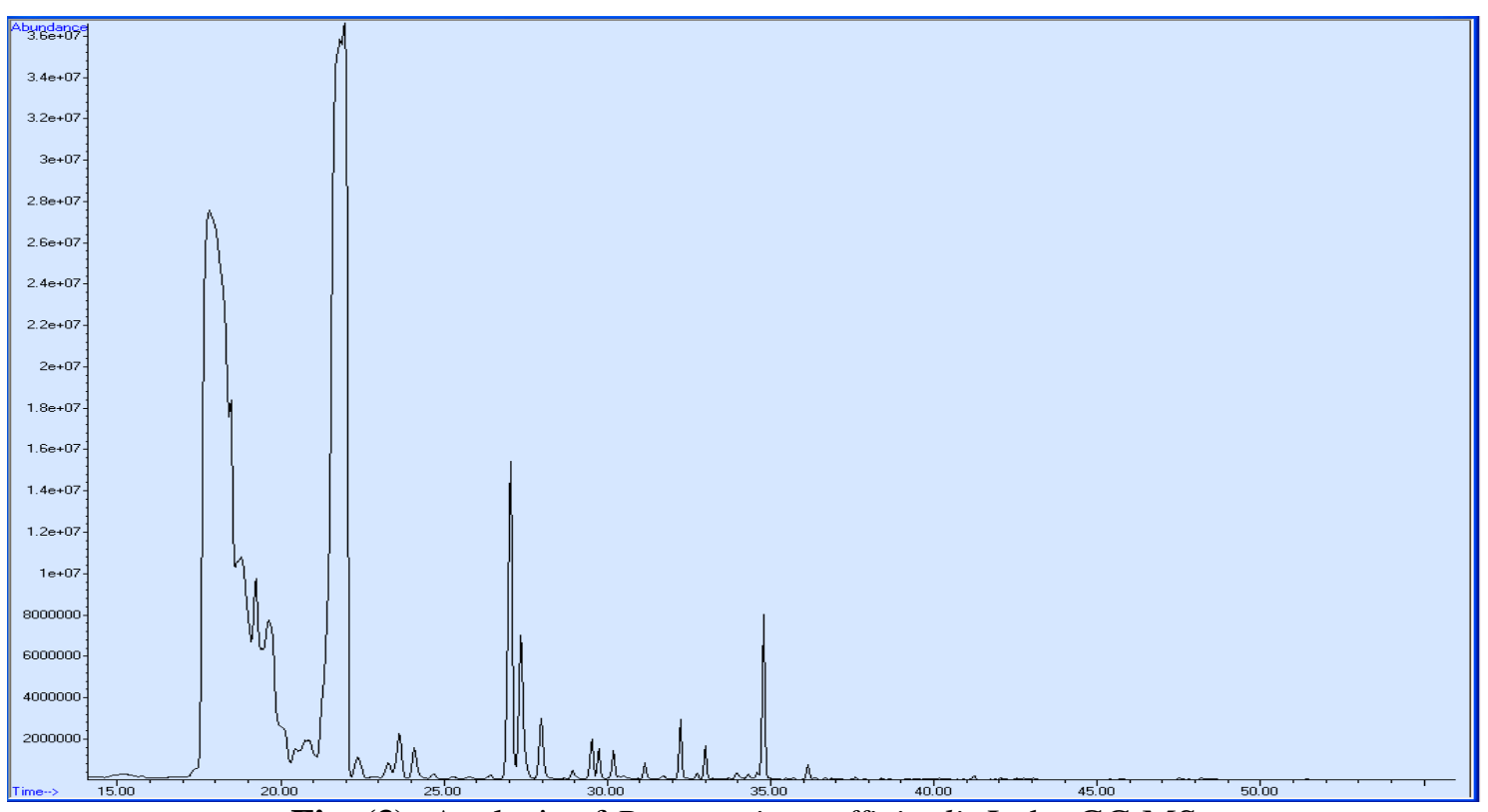

Fig. (3): Analysis of Rosamarinus officinalis L. by GC-MS 


\section{RESULT AND DISCUSSION:}

As shown in Table (5), the effect of different levels of thyme, adiantum, rosemary and their combination on broiler's lives body weight. In the male broiler, there are no differences between treated groups and the control group, while there are significantly different between treated groups during in the first week. In the second week, there is significantly lower body weight in the T8 group $(7.5 \mathrm{~g} / \mathrm{kg}$ of thyme and rosemary and $4 \mathrm{~g} / \mathrm{kg}$ of adiantum) as compared to the control group. In the $4^{\text {th }}$ and $5^{\text {th }}$ weeks, there is a significantly lower body weight when compared to the control group. The T6, T7 and $\mathrm{T} 8$ groups are significantly higher body weight than control groups at the $6^{\text {th }}$ week. Regard to female broiler chicken, at the $2^{\text {nd }}, 4^{\text {th }}$ and $5^{\text {th }}$ weeks there is no significant effect of medicinal plants on live body weight, while there are significantly effects between treated groups. The 7 group ( $10 \mathrm{~g} / \mathrm{kg}$ of rosemary) had significant effect of medicinal plant in improvement the live body weight as compared to the control group. The obtained result was an agreement with (Mathlouthi et al. 2015; Cetin et al. 2016; Soltani et al. 2016) who mentioned that adding thyme and rosemary powder or essential oil into the broiler diet or drinking water had a significantly different live body weight of chicks compared to control group. On the other hand, the results of the present study are not consistent with those of (Franciosini et al. 2015; Belenli et al. 2015). The lower live body weight in the T8 group may be due to the level of medicinal plants or health state of the experiment. The improvement in live body weight in the $\mathrm{T} 7$ group $(10 \mathrm{~g} / \mathrm{kg}$ of rosemary) may be due to the active ingredient such as anethole in anise and borneol in rosemary ( $\mathrm{Al}$ - Kassie, 2008). That was achieved anethole and borneol have digestive stimulating effects and Besides anethole and borneol affected pathogen microorganism in the digestive system and increased live weight gain and feed conversion (Cabuk et al., 2003).

Table (5): The effect of different levels of thyme, adiantum, rosemary and their combination on broiler's lives body weight (Mean \pm Standard error):

\begin{tabular}{|c|c|c|c|c|c|c|c|c|c|c|c|c|}
\hline \multirow{2}{*}{$\begin{array}{c}\text { Factor } \\
\text { Treatment }\end{array}$} & \multicolumn{2}{|c|}{$1^{\text {st }}$ Week } & \multicolumn{2}{|c|}{$2^{\text {nd }}$ Week } & \multicolumn{2}{|c|}{$3^{\text {rd }}$ Week } & \multicolumn{2}{|c|}{$4^{\text {th }}$ Week } & \multicolumn{2}{|c|}{$5^{\text {th }}$ Week } & \multicolumn{2}{|c|}{$6^{\text {th }}$ Week } \\
\hline & Male & Female & Male & Female & Male & Female & Male & Female & Male & Female & Male & Female \\
\hline \multirow[t]{2}{*}{$\mathrm{T} 1$} & 138.05 & 115.86 & 413.82 & 307.85 & 683.02 & 543.53 & 1196.36 & 895.26 & 1857.02 & 1516.03 & 2294.48 & 1918.69 \\
\hline & $\pm 4.83^{a b c}$ & $\pm 5.21^{a}$ & $\pm 22.29^{a}$ & $\pm 23.80^{\mathrm{ab}}$ & $\pm 38.60^{\mathrm{ab}}$ & $\pm 32.37^{a}$ & $\pm 51.18^{a}$ & $\pm 41.18^{a b}$ & $\pm 62.33^{\mathrm{a}}$ & $\pm 50.22^{a b}$ & $\pm 75.77^{\mathrm{c}}$ & $\pm 68.96^{b}$ \\
\hline \multirow[t]{3}{*}{ T2 } & 142.37 & 118.17 & 428.59 & 328.03 & 745.44 & 570.48 & 1206.49 & 921.52 & 1869.66 & 1537.76 & 2445.79 & 2018.26 \\
\hline & $\pm 4.32^{\mathrm{ab}}$ & $\pm 5.82^{a}$ & $\pm 19.94^{\mathrm{a}}$ & $\pm 26.61^{a}$ & $\pm 34.52^{\mathrm{a}}$ & $\pm 36.19^{a}$ & $\pm 45.78^{a}$ & $\pm 46.04^{\mathrm{ab}}$ & $\pm 55.75^{\mathrm{a}}$ & & $\pm 67.77^{\mathrm{abc}}$ & $\pm 77.09^{a b}$ \\
\hline & & & & & & & & & & $\pm 56.14^{\mathrm{a}}$ & & \\
\hline \multirow[t]{2}{*}{ T3 } & 130.83 & 113.98 & 379.78 & 290.43 & 592.38 & 477.68 & 1040.26 & 829.56 & 1595.99 & 1341.35 & 2437.32 & 1950.79 \\
\hline & $\pm 4.32^{\mathrm{bc}}$ & $\pm 5.82^{a}$ & $\pm 19.94^{\mathrm{ab}}$ & $\pm 26.61^{a b}$ & $\pm 34.52^{b}$ & $\pm 36.19^{a}$ & $\pm 45.78^{\mathrm{b}}$ & $\pm 46.04^{\mathrm{b}}$ & $\pm 55.75^{\mathrm{b}}$ & $\pm 56.14^{\mathrm{b}}$ & $\pm 67.77^{\mathrm{abc}}$ & $\pm 77.09^{\mathrm{b}}$ \\
\hline \multirow[t]{2}{*}{ T4 } & 146.46 & 123.79 & 419.92 & 230.25 & 695.23 & 492.97 & 1147.84 & 986.78 & 1764.75 & 1608.81 & 2629.58 & 2068.91 \\
\hline & $\pm 3.95^{\mathrm{a}}$ & $\pm 6.72^{a}$ & $\pm 18.20^{a}$ & $\pm 30.73^{b}$ & $\pm 31.52^{\mathrm{ab}}$ & $\pm 41.79^{a}$ & $\pm 41.79^{a b}$ & $\pm 53.16^{\mathrm{ab}}$ & $\pm 50.89^{\mathrm{ab}}$ & $\pm 64.83^{a}$ & $\pm 61.82^{\mathrm{a}}$ & $\pm 89.02^{a b}$ \\
\hline \multirow[t]{2}{*}{ T5 } & 137.31 & 119.51 & 376.41 & 324.78 & 612.53 & 470.55 & 1125.83 & 905.26 & 1763.99 & 1442.79 & 2424.07 & 2148.47 \\
\hline & $\pm 4.32^{a b c}$ & $\pm 5.82^{\mathrm{a}}$ & $\pm 19.94^{\mathrm{ab}}$ & $\pm 26.61^{\mathrm{a}}$ & $\pm 34.52^{b}$ & $\pm 36.19^{a}$ & $\pm 45.78^{\mathrm{ab}}$ & $\pm 46.04^{\mathrm{ab}}$ & $\pm 55.75^{\mathrm{ab}}$ & $\pm 56.14^{\mathrm{ab}}$ & $\pm 67.77^{\mathrm{abc}}$ & $\pm 77.09^{\mathrm{ab}}$ \\
\hline \multirow[t]{2}{*}{ T6 } & 138.35 & 119.82 & 404.76 & 328.11 & 625.92 & 520.43 & 1065.54 & 941.29 & 1695.58 & 1457.77 & 2583.65 & 2094.15 \\
\hline & $\pm 3.95^{\mathrm{abc}}$ & $\pm 6.72^{a}$ & $\pm 18.20^{a}$ & $\pm 30.73^{a}$ & $\pm 31.52^{b}$ & $\pm 41.79^{a}$ & $\pm 41.79^{a b}$ & $\pm 53.16^{\mathrm{ab}}$ & $\pm 50.89^{a b}$ & $\pm 64.83^{a b}$ & $\pm 61.82^{\mathrm{ab}}$ & $\pm 89.02^{a b}$ \\
\hline \multirow[t]{2}{*}{$\mathrm{T} 7$} & 148.62 & 120.41 & 423.97 & 320.34 & 676.71 & 553.42 & 1108.97 & 1008.77 & 1733.55 & 1556.24 & 2592.58 & 2273.45 \\
\hline & $\pm 4.32^{\mathrm{a}}$ & $\pm 5.82^{\mathrm{a}}$ & $\pm 19.94^{a}$ & $\pm 26.61^{\mathrm{ab}}$ & $\pm 34.52^{\mathrm{ab}}$ & $\pm 36.19^{a}$ & $\pm 45.78^{\mathrm{ab}}$ & $\pm 46.04^{\mathrm{a}}$ & $\pm 55.75^{\mathrm{ab}}$ & $\pm 56.14^{\mathrm{a}}$ & $\pm 67.77^{\mathrm{ab}}$ & $\pm 77.09^{a}$ \\
\hline \multirow[t]{2}{*}{ T8 } & 125.02 & 119.41 & 339.74 & 268.19 & 622.49 & 558.39 & 1061.19 & 1024.92 & 1730.15 & 1487.04 & 2396.45 & 2039.70 \\
\hline & $\pm 3.95^{c}$ & $\pm 6.72^{\mathrm{a}}$ & $\pm 18.20^{b}$ & $\pm 30.73^{\mathrm{ab}}$ & $\pm 31.52^{b}$ & $\pm 41.79^{a}$ & $\pm 41.79^{a b}$ & $\pm 53.16^{\mathrm{a}}$ & $\pm 50.89^{\mathrm{ab}}$ & $\pm 64.83^{\mathrm{ab}}$ & $\pm 61.82^{\mathrm{bc}}$ & $\pm 89.02^{\mathrm{ab}}$ \\
\hline
\end{tabular}

${ }^{* a, b, c, ~ M e a n s ~ w i t h ~ d i f f e r e n t ~ s u p e r s c r i p t s ~ i n ~ t h e ~ s a m e ~ c o l u m n ~ d i f f e r ~ s i g n i f i c a n t l y ~}(\mathrm{P}<0.05) . \mathrm{T} 1=$ control, T2=Thyme

$5 \mathrm{~g} / \mathrm{kg}$, T3=Thyme $10 \mathrm{~g} / \mathrm{kg}$, T4= Adiantum $3 \mathrm{~g} / \mathrm{kg}$, T5=Adiantum $5 \mathrm{~g} / \mathrm{kg}$, T6= Rosemary $5 \mathrm{~g} / \mathrm{kg}, \mathrm{T} 7=$ Rosemary

$10 \mathrm{~g} / \mathrm{kg}, \mathrm{T} 8=$ Thyme $7.5 \mathrm{~g} / \mathrm{kg}+$ Adiantum g/kg+ Rosemary $7.5 \mathrm{~g} / \mathrm{kg}$. 
Table (6), shown the impact of different levels of thyme, adiantum, rosemary and their combination on carcass cuts and dressing percentage of the broiler. In the male broiler, the carcass yield weight in T2, T3 and T8 groups had significant improvement than the control group. T3 group (thyme $10 \mathrm{~g} / \mathrm{kg}$ ) had a significant improvement in the dressing present than a control group. Regard to female broiler chicken, there is no significant effect of medicinal plants in carcass yield, dressing present, breast, leg and wing weights as compared to the control group. The T3 group (thyme $10 \mathrm{~g} / \mathrm{kg}$ ) had significant affect on neck and back weight when compared to the control group. The results of the present study are similar to those El-Ghousein and Al-Beitawi (2009); AL-Kassie (2009) founded a significant effect of thyme powder in broiler diet on dressing percentage when compared to control group. In contrast, the result disagreed of those AL Khdri (2013); Ayoola et al. (2014) that observed added thyme powder in broiler diet had no effect on dressing percentage compared to the control group. Regarding back and neck weight, the result of our study have disagreed with those found (Ayoola et al. 2014; Al-Mashhadani 2014) they reported that thyme powder did not effect on neck and/or back weight compared to control group.

The improvement of carcass yield may be due to some reasons likewise the presence of phenolic and antioxidants substance in thyme may be the basic motive of improvement in carcass yield weight of broilers chicken (Lee et al. 2003; Gulcin et al. 2004). The presence groups of harmful bacterial in the gastrointestinal tract perhaps main cause breakdown of amino acids and therefore decrease their absorption as antimicrobial substances are present in thyme can decrease the harmful bacterial populations in the gastrointestinal tract and speed up the amount of absorbed amino acids (Lee et al. 2003; Gulcin et al. 2004). The main substance presence in thyme is carvacrol which has stimulatory effects on pancreatic secretions through increased the secretions of digestive enzymes more amounts of nutrients like amino acids can be digested and absorbed from the digestive tract and through improves carcass traits (Lee et al. 2003).

Table (6): The influence of different levels of thyme, adiantum, rosemary and their combination on carcass cuts and dressing percentage of broiler (Mean \pm Standard Error):

\begin{tabular}{|c|c|c|c|c|c|c|c|c|c|c|c|c|}
\hline \multirow{2}{*}{$\begin{array}{c}\text { Factor } \\
\text { Treatment }\end{array}$} & \multicolumn{2}{|c|}{ Carcass yield (g) } & \multicolumn{2}{|c|}{ Dressing $\%$} & \multicolumn{2}{|c|}{ Breast (g) } & \multicolumn{2}{|c|}{ Legs $(\mathrm{g})$} & \multicolumn{2}{|c|}{ Wing (g) } & \multicolumn{2}{|c|}{ Neck and Back (g) } \\
\hline & Male & Female & Male & Female & Male & Female & Male & Female & Male & Female & Male & Female \\
\hline \multirow[t]{2}{*}{ T1 } & 1244 & 1266 & 66.85 & & 455.67 & & 341 & 358 & 144.67 & & 375 & 340 \\
\hline & $\pm 57.64^{\mathrm{b}}$ & $\pm 69.32^{\mathrm{ab}}$ & $\pm 1.18^{\mathrm{b}}$ & $\pm 1.17^{\mathrm{a}}$ & $\pm 19.03^{\mathrm{a}}$ & $\pm 32.2^{\mathrm{ab}}$ & $\pm 14.63^{\mathrm{cd}}$ & $\pm 21.84^{\mathrm{ab}}$ & $\pm 6.66^{c}$ & $\pm 9.29^{\mathrm{ab}}$ & $\pm 20.93^{b}$ & $\pm 23.86^{\mathrm{b}}$ \\
\hline \multirow[t]{2}{*}{ T2 } & 1442 & 1412.67 & 66.62 & 67.95 & 464.67 & 461.33 & 384.67 & 385.33 & 162.33 & 176 & 394 & 376.67 \\
\hline & $\pm 57.64^{\mathrm{a}}$ & $\pm 69.32^{\mathrm{ab}}$ & $\pm 1.18^{\mathrm{b}}$ & $\pm 1.17^{\mathrm{a}}$ & $\pm 19.03^{a}$ & $\pm 32.2^{\mathrm{ab}}$ & $\pm 14.63^{\mathrm{bc}}$ & $\pm 21.84^{\mathrm{a}}$ & $\pm 6.66^{\mathrm{bc}}$ & $\pm 9.29^{\mathrm{a}}$ & $\pm 20.93^{\mathrm{ab}}$ & $\pm 23.86^{\mathrm{ab}}$ \\
\hline \multirow[t]{2}{*}{ T3 } & 1259 & 1438 & 76.61 & 70.41 & 444.67 & 445 & 452.67 & 376.33 & 183.33 & 168.67 & 450 & 423.67 \\
\hline & $\pm 57.64^{\mathrm{a}}$ & $\pm 69.32^{\mathrm{a}}$ & $\pm 1.18^{\mathrm{a}}$ & $\pm 1.17^{\mathrm{a}}$ & $\pm 19.03^{\mathrm{ab}}$ & $\pm 32.2^{\mathrm{ab}}$ & $\pm 14.63^{\mathrm{a}}$ & $\pm 21.84^{\mathrm{ab}}$ & $\pm 6.66^{a}$ & $\pm 9.29^{\mathrm{ab}}$ & $\pm 20.93^{\mathrm{a}}$ & $\pm 23.86^{\mathrm{a}}$ \\
\hline \multirow[t]{2}{*}{ T4 } & 1351 & 1376 & 69.78 & 69.93 & 424 & 431 & 403.67 & 368.67 & 161.33 & 175.33 & 352 & 394.67 \\
\hline & $\pm 57.64^{\mathrm{ab}}$ & $\pm 69.32^{\mathrm{ab}}$ & $\pm 1.18^{\mathrm{b}}$ & $\pm 1.17^{\mathrm{a}}$ & $\pm 19.03^{\mathrm{ab}}$ & $\pm 32.2^{\mathrm{ab}}$ & $\pm 14.63^{\mathrm{b}}$ & $\pm 21.84^{\mathrm{ab}}$ & $\pm 6.66^{\mathrm{bc}}$ & $\pm 9.29^{a}$ & $\pm 20.93^{b}$ & $\pm 23.86^{\mathrm{ab}}$ \\
\hline \multirow[t]{2}{*}{ T5 } & 1224 & 1195.67 & 67.65 & 65.86 & 410 & 384.33 & 330.67 & 310 & 144.67 & 144.67 & 326 & 356.67 \\
\hline & $\pm 57.64^{\mathrm{b}}$ & $\pm 69.32^{b}$ & $\pm 1.18^{b}$ & $\pm 1.17^{\mathrm{a}}$ & $\pm 19.03^{\mathrm{ab}}$ & $\pm 32.2^{\mathrm{ab}}$ & $\pm 14.63^{d}$ & $\pm 21.84^{\mathrm{b}}$ & $\pm 6.66^{c}$ & $\pm 9.29^{b}$ & $\pm 20.93^{b}$ & $\pm 23.86^{\mathrm{ab}}$ \\
\hline \multirow[t]{2}{*}{ T6 } & 1236 & 1278.67 & 67.47 & 70.46 & 387.33 & 375.33 & 355.33 & 356 & 142 & 142 & 342 & 328.67 \\
\hline & $\pm 57.64^{b}$ & $\pm 69.32^{\mathrm{ab}}$ & $\pm 1.18^{b}$ & $\pm 1.17^{\mathrm{a}}$ & $\pm 19.03^{b}$ & $\pm 32.2^{\mathrm{b}}$ & $\pm 14.63^{\mathrm{bcd}}$ & $\pm 21.84^{\mathrm{ab}}$ & $\pm 6.66^{c}$ & $\pm 9.29^{b}$ & $\pm 20.93^{b}$ & $\pm 23.86^{\mathrm{b}}$ \\
\hline \multirow[t]{2}{*}{$\mathrm{T7}$} & 1386 & 1382.33 & 69.07 & 67.76 & 425 & 412.33 & 392 & 380.67 & 176.33 & 172 & 377.67 & 359.33 \\
\hline & $\pm 57.64^{\mathrm{ab}}$ & $\pm 69.32^{\mathrm{ab}}$ & $\pm 1.18^{b}$ & $\pm 1.17^{\mathrm{a}}$ & $\pm 19.03^{\mathrm{ab}}$ & $\pm 32.2^{\mathrm{ab}}$ & $\pm 14.63^{b}$ & $\pm 21.84^{\mathrm{ab}}$ & $\pm 6.66^{\mathrm{ab}}$ & $\pm 9.29^{\mathrm{ab}}$ & $\pm 20.93^{b}$ & $\pm 23.86^{\mathrm{ab}}$ \\
\hline \multirow[t]{2}{*}{ T8 } & 1446 & 1458 & 70.19 & 67.68 & 450 & 486.33 & 362.33 & 404.33 & 147.33 & 141 & 366 & 370.67 \\
\hline & $\pm 57.64^{\mathrm{a}}$ & $\pm 69.32^{\mathrm{a}}$ & $\pm 1.18^{b}$ & $\pm 1.17^{\mathrm{a}}$ & $\pm 19.03^{\mathrm{ab}}$ & $\pm 32.2^{\mathrm{a}}$ & $\pm 14.63^{\mathrm{bcd}}$ & $\pm 21.84^{a}$ & $\pm 6.66^{c}$ & $\pm 9.29^{b}$ & $\pm 20.93^{b}$ & $\pm 23.86^{\mathrm{ab}}$ \\
\hline
\end{tabular}

*a, b, c, Means with different superscripts in the same column differ significantly $(\mathrm{P}<0.05)$.T1= control, T2=Thyme

$5 \mathrm{~g} / \mathrm{kg}$, T3=Thyme $10 \mathrm{~g} / \mathrm{kg}$, T4= Adiantum $3 \mathrm{~g} / \mathrm{kg}$, T5=Adiantum $5 \mathrm{~g} / \mathrm{kg}$, T6= Rosemary $5 \mathrm{~g} / \mathrm{kg}$, T7=Rosemary

$10 \mathrm{~g} / \mathrm{kg}$, T8=Thyme $7.5 \mathrm{~g} / \mathrm{kg}+$ Adiantum g/kg+ Rosemary $7.5 \mathrm{~g} / \mathrm{kg}$. 
Table (7), shown the impact of different levels of medicinal plants in the internal organs of broiler chicken. In the male, there are no significant effect of different type and levels of medicinal plants in the heart, gizzard, liver and abdominal fat weight as compared to control group, while there is a significant effect of medicinal plants in heart between treated groups. Regards to female broiler chicken, there is no difference between treated groups and control group in heart, gizzard, liver and abdominal fat weight. The gizzard and liver weight had significantly affected by different types and levels of medicinal plants between treated groups. Fat abdominal, the result of our study was similar to these researchers (Mansoub et al. (2011); Pourmahmoud et al. (2016) achieved that thyme powder in broiler diet had a significant effect on the relative weight of fat abdominal compared to control group. In contrast, the result is not consistent with those of
(Sadeghi et al. (2011); Al-Mashhadani (2014). Liver, the result was in agreement with (ALKassie (2009); Abdulkarimi et al. (2011) reported that the relative weight of liver significantly differences compared to the control group when added thyme or rosemary in broiler diet. While our result has disagreed of those (Sadeghi et al. (2011); Pourmahmoud et al. (2016) reported that broiler chicken fed different levels of thyme or rosemary had no effect in the relative weight of the liver compared to control group. It has been reported that the digestive system of poultry could be more activation by oil extracts from herbs, nevertheless improve the function of liver and increasing the pancreatic digestive enzymes. Enhancement of the metabolism of carbohydrates, proteins and oil in the most organs which lead to increase the growth rate of the liver weight (Mellor, 2000a; 2000b).

Table (7): The effect of different level of thyme, rosemary, adiantum and their combination on internal organ weights of broiler chickens gender (Mean \pm Standard error):

\begin{tabular}{|c|c|c|c|c|c|c|c|c|}
\hline \multirow{2}{*}{$\begin{array}{r}\text { Factor } \\
\text { Treatment }\end{array}$} & \multicolumn{2}{|c|}{ Hearts (g) } & \multicolumn{2}{|c|}{ Gizzard (g) } & \multicolumn{2}{|c|}{ Liver (g) } & \multicolumn{2}{|c|}{ Abdominal fat $(\mathrm{g})$} \\
\hline & Male & Female & Male & Female & Male & Female & Male & Female \\
\hline \multirow[t]{2}{*}{ T1 } & 10.27 & 8.19 & 25.27 & 25.08 & 39.36 & 40.09 & 13.16 & 13.97 \\
\hline & $\pm 0.76^{\mathrm{ab}}$ & $\pm 1.38^{a}$ & $\pm 1.67^{a}$ & $\pm 1.61^{\mathrm{ab}}$ & $\pm 3.29^{a}$ & $\pm 3.16^{\mathrm{ab}}$ & $\pm 2.11^{\mathrm{a}}$ & $\pm 2.51^{\mathrm{a}}$ \\
\hline \multirow[t]{2}{*}{ T2 } & 8.92 & 9.72 & 27.77 & 23.52 & 42.71 & 37.88 & 16.48 & 7.51 \\
\hline & $\pm 0.76^{\mathrm{ab}}$ & $\pm 1.38^{a}$ & $\pm 1.67^{\mathrm{a}}$ & $\pm 1.61^{\mathrm{ab}}$ & $\pm 3.29^{a}$ & $\pm 3.16^{\mathrm{ab}}$ & $\pm 2.11^{\mathrm{a}}$ & $\pm 2.51^{\mathrm{a}}$ \\
\hline \multirow[t]{2}{*}{ T3 } & 10.97 & 12.14 & 23.30 & 22.78 & 47.38 & 47.14 & 12.82 & 12.58 \\
\hline & $\pm 0.76^{a}$ & $\pm 1.38^{\mathrm{a}}$ & $\pm 1.67^{\mathrm{a}}$ & $\pm 1.61^{\mathrm{ab}}$ & $\pm 3.29^{a}$ & $\pm 3.16^{\mathrm{a}}$ & $\pm 2.11^{\mathrm{a}}$ & $\pm 2.51^{\mathrm{a}}$ \\
\hline \multirow[t]{2}{*}{ T4 } & 9.64 & 9.42 & 26.09 & 25.29 & 41.58 & 37.42 & 15.92 & 18.17 \\
\hline & $\pm 0.76^{\mathrm{ab}}$ & $\pm 1.38^{\mathrm{a}}$ & $\pm 1.67^{\mathrm{a}}$ & $\pm 1.61^{\mathrm{ab}}$ & $\pm 3.29^{a}$ & $\pm 3.16^{\mathrm{ab}}$ & $\pm 2.11^{\mathrm{a}}$ & $\pm 2.51^{\mathrm{a}}$ \\
\hline \multirow[t]{2}{*}{ T5 } & 11.41 & 9.66 & 26.72 & 23.75 & 44.95 & 44.04 & 17.87 & 18.66 \\
\hline & $\pm 0.76^{a}$ & $\pm 1.38^{\mathrm{a}}$ & $\pm 1.67^{a}$ & $\pm 1.61^{\mathrm{ab}}$ & $\pm 3.29^{a}$ & $\pm 3.16^{\mathrm{ab}}$ & $\pm 2.11^{\mathrm{a}}$ & $\pm 2.51^{\mathrm{a}}$ \\
\hline \multirow[t]{2}{*}{ T6 } & 9.06 & 9.40 & 25.14 & 24.17 & 43.81 & 37.88 & 15.93 & 15.03 \\
\hline & $\pm 0.76^{\mathrm{ab}}$ & $\pm 1.38^{\mathrm{a}}$ & $\pm 1.67^{a}$ & $\pm 1.61^{\mathrm{ab}}$ & $\pm 3.29^{\mathrm{a}}$ & $\pm 3.16^{\mathrm{ab}}$ & $\pm 2.11^{\mathrm{a}}$ & $\pm 2.51^{\mathrm{a}}$ \\
\hline \multirow[t]{2}{*}{ T7 } & 9.11 & 9.47 & 23.20 & 27.47 & 41.33 & 36.14 & 15.38 & 17.16 \\
\hline & $\pm 0.76^{\mathrm{ab}}$ & $\pm 1.38^{\mathrm{a}}$ & $\pm 1.67^{\mathrm{a}}$ & $\pm 1.61^{\mathrm{a}}$ & $\pm 3.29^{a}$ & $\pm 3.16^{b}$ & $\pm 2.11^{\mathrm{a}}$ & $\pm 2.51^{\mathrm{a}}$ \\
\hline \multirow[t]{2}{*}{ T8 } & 8.11 & 10.43 & 26.66 & 21.41 & 43.94 & 45.81 & 13.16 & 13.46 \\
\hline & $\pm 0.76^{b}$ & $\pm 1.38^{\mathrm{a}}$ & $\pm 1.67^{a}$ & $\pm 1.61^{b}$ & $\pm 3.29^{a}$ & $\pm 3.16^{\mathrm{ab}}$ & $\pm 2.11^{\mathrm{a}}$ & $\pm 2.51^{\mathrm{a}}$ \\
\hline
\end{tabular}

*a, b Means with different superscripts in the same row differ significantly $(\mathrm{P}<0.05)$. T1= control, T2=Thyme 5 $\mathrm{g} / \mathrm{kg}$, T3=Thyme $10 \mathrm{~g} / \mathrm{kg}$, T4= Adiantum $3 \mathrm{~g} / \mathrm{kg}$, T5=Adiantum 5 g/kg, T6= Rosemary 5 g/kg, T7=Rosemary 10 $\mathrm{g} / \mathrm{kg}$, T8=Thyme $7.5 \mathrm{~g} / \mathrm{kg}+$ Adiantum g/kg+ Rosemary $7.5 \mathrm{~g} / \mathrm{kg}$. 
Table (8), shown the influence of different levels of thyme, rosemary, adiantum and their combination in lymphoid organs of broiler chickens. There are no significant effects of different types and levels of medicinal plants in lymphoid organs of both male and female broiler chicken, while there is a significant effect between treated groups in bursa weight of male broiler. These authors (Zeweil et al. (2015);
Hashemipour et al. (2016); Pourmahmoud et al. (2016) achieved the same results as we did and they did not find any effect of thyme and/ or rosemary on the relative weight of bursa and spleen in the broiler chicks compared to control group. Otherwise, the results are not consistent with those of (Saleh et al. 2014; Al-Mashhadani 2014).

Table (8): The influence of different levels of thyme, rosemary, adiantum and their combination on lymphoid organs of broiler chickens (Mean \pm Standard error):

\begin{tabular}{ccccc}
\hline Factor & \multicolumn{2}{c}{ Bursa $(\mathrm{g})$} & Male & Female \\
\hline Treatment & Male & Female & $2.24 \pm 0.29^{\mathrm{a}}$ & $2.17 \pm 0.23^{\mathrm{a}}$ \\
\hline T1 & $1.47 \pm 0.16^{\mathrm{ab}}$ & $1.77 \pm 0.23^{\mathrm{a}}$ & $2.13 \pm 0.29^{\mathrm{a}}$ & $1.95 \pm 0.23^{\mathrm{a}}$ \\
\hline T2 & $1.41 \pm 0.16^{\mathrm{ab}}$ & $1.53 \pm 0.23^{\mathrm{a}}$ & $1.77 \pm 0.29^{\mathrm{a}}$ & $1.86 \pm 0.23^{\mathrm{a}}$ \\
\hline T3 & $1.34 \pm 0.16^{\mathrm{b}}$ & $1.51 \pm 0.23^{\mathrm{a}}$ & $2.70 \pm 0.29^{\mathrm{a}}$ & $2.55 \pm 0.23^{\mathrm{a}}$ \\
\hline T4 & $1.35 \pm 0.16^{\mathrm{b}}$ & $1.59 \pm 0.23^{\mathrm{a}}$ & $2.05 \pm 0.29^{\mathrm{a}}$ & $2.01 \pm 0.23^{\mathrm{a}}$ \\
\hline T5 & $1.89 \pm 0.16^{\mathrm{a}}$ & $1.64 \pm 0.23^{\mathrm{a}}$ & $2.11 \pm 0.29^{\mathrm{a}}$ & $1.94 \pm 0.23^{\mathrm{a}}$ \\
\hline T6 & $1.49 \pm 0.16^{\mathrm{ab}}$ & $1.44 \pm 0.23^{\mathrm{a}}$ & $1.93 \pm 0.29^{\mathrm{a}}$ & $1.92 \pm 0.23^{\mathrm{a}}$ \\
\hline T7 & $1.25 \pm 0.16^{\mathrm{b}}$ & $1.30 \pm 0.23^{\mathrm{a}}$ & $2.63 \pm 0.29^{\mathrm{a}}$ & $2.31 \pm 0.23^{\mathrm{a}}$
\end{tabular}

*a, b, Means with different superscripts in the same column differ significantly $(\mathrm{P}<0.05)$.T1= control, T2=Thyme $5 \mathrm{~g} / \mathrm{kg}$, T3=Thyme $10 \mathrm{~g} / \mathrm{kg}$, T4= Adiantum $3 \mathrm{~g} / \mathrm{kg}$, T5=Adiantum 5 g/kg, T6= Rosemary 5 g/kg, T7=Rosemary $10 \mathrm{~g} / \mathrm{kg}, \mathrm{T} 8=$ Thyme $7.5 \mathrm{~g} / \mathrm{kg}+$ Adiantum g/kg+ Rosemary $7.5 \mathrm{~g} / \mathrm{kg}$. N.S = not significant.

Table (9), shown the influence of different levels of thyme, rosemary, adiantum and their combination on meat color of broiler chickens. There are no significant effects of the difference of medicinal plants in meat color than the control group. In the male, There are a significant effect of medicinal plants between the treated groups in redness $\left(\mathbf{a}^{*}\right)$ color. In the female, there is a significant effects of medicinal plants in yellowness $\left(\mathrm{b}^{*}\right)$ color between treated groups. According to our knowledge, there is no previous study done on this parameter to describe the reason behind this. The result was in agreement with the finding of (Jang et al. 2011; An et al. 2015) who's reported that using dietary quercetin and methoxylated quercetin extracted from onion or dietary onion in broiler diet had no significantly affected in broiler's meat color. 
Table (9): The influence of different levels of thyme, rosemary, adiantum and their combination on meat color of broiler chickens (Mean \pm Standard error):

\begin{tabular}{|c|c|c|c|c|c|c|}
\hline \multirow{2}{*}{$\begin{array}{c}\text { Factor } \\
\text { Treatment }\end{array}$} & \multicolumn{2}{|c|}{$L^{*}$} & \multicolumn{2}{|c|}{$a^{*}$} & \multicolumn{2}{|c|}{$b^{*}$} \\
\hline & Male & Female & Male & Female & Male & Female \\
\hline T1 & $53.52 \pm 2.69^{a}$ & $52.77 \pm 2.85^{\mathrm{a}}$ & $2.13 \pm 0.41^{\mathrm{a}}$ & $1.40 \pm 0.5^{\mathrm{a}}$ & $6.23 \pm 1.26^{a}$ & $7.44 \pm 0.74^{\mathrm{ab}}$ \\
\hline T2 & $55.89 \pm 2.69^{a}$ & $52.68 \pm 2.85^{a}$ & $1.34 \pm 0.41^{\mathrm{ab}}$ & $1.09 \pm 0.5^{a}$ & $6.30 \pm 1.26^{a}$ & $6.91 \pm 0.74^{\mathrm{ab}}$ \\
\hline T3 & $52.55 \pm 2.69^{a}$ & $49.95 \pm 2.85^{\mathrm{a}}$ & $1.02 \pm 0.41^{\mathrm{ab}}$ & $1.94 \pm 0.5^{a}$ & $6.20 \pm 1.26^{a}$ & $6.63 \pm 0.74^{\mathrm{ab}}$ \\
\hline T4 & $55.43 \pm 2.69^{a}$ & $51.26 \pm 2.85^{\mathrm{a}}$ & $1.32 \pm 0.41^{\mathrm{ab}}$ & $2.14 \pm 0.5^{a}$ & $6.39 \pm 1.26^{a}$ & $7.88 \pm 0.74^{\mathrm{ab}}$ \\
\hline T5 & $52.45 \pm 2.69^{a}$ & $49.50 \pm 2.85^{a}$ & $1.20 \pm 0.41^{\mathrm{ab}}$ & $1.20 \pm 0.5^{\mathrm{a}}$ & $6.01 \pm 1.26^{\mathrm{a}}$ & $6.69 \pm 0.74^{\mathrm{ab}}$ \\
\hline T6 & $54.98 \pm 2.69^{a}$ & $52.48 \pm 2.85^{\mathrm{a}}$ & $1.03 \pm 0.41^{\mathrm{ab}}$ & $1.14 \pm 0.5^{\mathrm{a}}$ & $7.97 \pm 1.26^{\mathrm{a}}$ & $8.29 \pm 0.74^{a}$ \\
\hline T7 & $55.63 \pm 2.69^{a}$ & $51.34 \pm 2.85^{\mathrm{a}}$ & $1.18 \pm 0.41^{\mathrm{ab}}$ & $1.27 \pm 0.5^{\mathrm{a}}$ & $8.64 \pm 1.26^{a}$ & $5.60 \pm 0.74^{b}$ \\
\hline T8 & $53.14 \pm 2.69^{a}$ & $50.31 \pm 2.85^{\mathrm{a}}$ & $0.36 \pm 0.41^{b}$ & $1.19 \pm 0.5^{\mathrm{a}}$ & $6.23 \pm 1.26^{a}$ & $6.17 \pm 0.74^{\mathrm{ab}}$ \\
\hline
\end{tabular}

*a, b, Means with different superscripts in the same row differ significantly $(\mathrm{P}<0.05) . \mathrm{T} 1=$ control, T2=Thyme 5 g/kg, T3=Thyme 10 g/kg, T4= Adiantum 3 g/kg, T5=Adiantum 5 g/kg, T6= Rosemary 5 g/kg, T7=Rosemary 10 $\mathrm{g} / \mathrm{kg}$, T8=Thyme $7.5 \mathrm{~g} / \mathrm{kg}+$ Adiantum $\mathrm{g} / \mathrm{kg}+$ Rosemary $7.5 \mathrm{~g} / \mathrm{kg}$. L*= lightness, $\mathrm{a}^{*}=$ redness; $\mathrm{b}^{*}=$ yellowness.

\section{CONCLUSION}

1. In general the medicinal herbs powder supplements in broiler's diet have a beneficial effect on most of broiler performance. Higher live body weight was recorded at $\mathrm{T} 4$ group (Adiantum $4 \mathrm{~g} / \mathrm{kg}$ ) and $\mathrm{T} 7$ group (Rosemary 10 $\mathrm{g} / \mathrm{kg}$ ) and male was heavier than female weight.

2. Various levels of dietary herbs treatments had effect on carcass traits and T3 group (thyme 10 $\mathrm{g} / \mathrm{kg}$ ) had best recorded dressing percentage.

3. The male broiler chicks had higher live body weight, carcass yield and carcass cut weight when compared with female.

4. In general redness, yellowness and lightness of meat did not change by added herbs to broiler diets.

\section{REFERENCES}

Abd-El-Latif ASA, Saleh NS, Allam TS, Ghazy EW (2013) The effects of rosemary (Rosemarinus afficinalis) and garlic (Allium sativum) essential oils on performance, hematological, biochemical and immunological parameters of broiler chickens. Br J Poult Sci 2(2): 16-24

Abdulkarimi R (2011) Immune response of broiler chickens supplemented with thyme extract (Thymus vulgaris) in drinking water. Annals ofBiological Research 2: 208-212

$\mathrm{Al}$ - Kassie GAM (2008) the Effect of Anise and Rosemary on Broiler Performance. International Journal of Poultry Science 7 (3): $243-245$
Ali AHH (2014) Productive performance and immune response of broiler chicks as affected by dietary thyme leaves powder. Egypt. Poult. Sci Vol 34(I): 71-84

Al-Kassie GAM (2009) Influence of two plant extracts derived from thyme and cinnamon on broiler performance. Pakistan Vet. J 29(4): $169-173$

Al-Kassie GAM, Abd-Al-Jaleel RA, Mohseen AM (2011) the effect of a mixture of anise and rosemary on broiler performance. Agric. Biol. J. N. Am 2(9): 1279-1282

Al-Khdri AMA (2013) Effect of ginger (zingiber officinale) and thyme (thymus vulgaris) dietary supplementation on productive and immunological performance of broiler. Faculty of Agriculture and Forestry School of Animal Production Kurdistan Regional Government-Iraq master thesis

Al-Mashhadani HE (2014) Effect of supplementing different levels of ginger, thyme and their mixture on broiler performance, carcass characteristics and bacterial count. Res. Opin. Anim. Vet. Sci 4(12): 689-694

Ambusta SP (Ed.) (1986) The Useful Plants of India. Publications and Information

An BK, Kim JY, Oh ST, Kang CW, Cho S, Kim SK (2015) Effects of Onion Extracts on Growth Performance, Carcass Characteristics and Blood Profiles of White Mini Broilers. Asian Australas. J. Anim. Sci 28: 247-251

Ayoola MA, Adedeji OA, Oladepo AD (2014)Effects of Dietary Thyme Leaf on Broiler Growth Performances, Carcass Characteristics and 
Cooking Yield of the Meat. Glob. J. Sci. Res 2(2): 47-50

Basmacioglu H, Tokusoglu O, Ergul M (2004) The effect of oregano and rosemary essential oils or alpha-tocopheryl acetate on performance and lipid oxidation of meat enriched with n-3 PUFA's in broilers. South Afr. J. Anim. Sci 34: $197-210$

Belenli D, Duygu Udum, Şule Cengiz S,Ümit Polat (2015)Influence of Various Volatile Oils as a Dietary Supplement on Biochemical and Performance Parameters in Broilers.J. Biol. Environ. SCI 9(25): 47-55

Brugalli I (2003) Alimentacao alternativa: a utilizacao de fitoterapicos ou nutraceuticos como moduladores da imunidade e desempenho animal. Anais Do Simposio Sobre Manejo E Nutricao De Aves E Suínos; Campinas, Sao Paulo. Brasil. Campinas: CBNA, Pp: 167-182.

Cabuk M, Alcicek A, Bozkurt M, Imre N (2003) Antimicrobial properties of the essential oils isolated from aromatic plants and using possibility as alternative feed additives. II. National Animal Nutrtion Congress, 18-20. September, pp: 184-187

Cabuk M, Bozkurt M, Alcicek A, Akbas Y, Kucukyilmaz K (2006) Effect of a herbal essential oil mixture on growth and internal organ weight of broilers from young and old breeder flocks. South Afr. J. Anim. Sci 36: 135-141

Cetin E, Yibar A, Yesilbag D, Cetin I, Cengiz SS (2016) The effect of volatile oil mixtures on the performance and ilio-caecal microflora of broiler chickens. British Poultry Science · July DOI: 10.1080/00071668.2016.1214682

Cuvelier ME, Richard H, Berset C (1996) Antioxidative activity and phenolic composition of pilot-plant and commercial extracts of sage and rosemary. J. AOCS 73: 645-652

Dahiya JP, Wilkie DC, Van Kessel AG, Drew MD ( 2006) Potential strategies for controlling necrotic enteritis in broiler chickens in postantibiotic era. Anim. Feed Sci. Technol. 129: 60-68.

Dalkiliç B, Güler T (2009) The Effects of clove extract supplementation on performance and digestibility of Nutrients in broilers. F.Ü. Sağ. Bil. Vet. Derg 23: 161-166.

Demir E, Sarica S, Ozcan MA, Suicmez M (2008) The use of natural feed additives as alternative to an antibiotic growth promoter in broiler diets. Arch. fur Geflugelkunde 69(3): 110-116.

Directorate, Council for Scientific and Industrial Research, New Delhi
Dorman HJD, Deans SG, (2000) Antimicrobial agents from plants: antimicrobial activity of plant volatile oils. Journal of Applied Microbiology 88: 308-316.

Duncan, D.B. (1955). Multiple ranges and multiple f. test. Biometric. 11:42

El-Ghousein SS,Al-Beitawi NA (2009) The effect of feeding of crushed thyme (Thymus Vulgaris L) on Growth, blood constituents, gastrointestinal Tract and carcass characteristics of broiler chickens. J.Poult. Sci. 46: 100-104

Gollnisch K, Halle I (2001) Effects of essential oils and herb in animal nutrition. Proc. 8th Symp.in Vitamins and Additives in Nutrition of Man and Animal. pp. , Jena, Thüringen, Sept 32(Abstr.), 26-27.

Gülçin I, Küfrevioğlu K, Oktay M, Büyükokuroğlu ME (2004).J. Ethnopharacology90: 205-215

Hashemipour H, Kermanshahi H, Golian A, Veldkamp $T$ (2016) Effect of thymol and carvacrol feed supplementation on performance, antioxidant enzyme activities, fatty acid composition, digestive enzyme activities, and immune response in broiler chickens. Poultry Science 92: 2059-2069

Husson GP, Vilagines R, Delavean P (1986) research into antiviral properties of a new natural extract. Ann Pharin. Fr 44: 41

Jang A, Ham JA, Kim DW, Chae HS, Kim DW, Kim SH, Seol KH, Oh MW, Kim DH (2011) Effect of quercetin and methoxylated quercetin on chicken thigh meat quality during cold storage. Korean J. Poult. Sci 38:265-273

Lee KW, Everts H, Beynen AC (2004b) Essential oils in broiler nutrition. International journal of poultry science 3: 738-752.

Lee KW, Everts H, Kappert HJ, Frehner M, Losa R, Beynen AC (2003) Effects of dietary essential oil components on growth performance, digestive enzymes and lipid metabolism in female broiler chickens. British Poultry Science 44: 450-457

Mansoub NH, Myandoab MP (2011) The effect of different levels of thyme on performance, carcass traits and blood parameters of broilers. Annals of Biological Research 2(4): 379- 385

Masada Y. (1976) Analysis of oils by gas chromatography and mass spectrometry. Johan Wiley and Sons.

Mikaili P, Mohammad Nezhady MA, Shayegh J, Asghari MH (2010) International Journal of Academic Research Vol. 2. No. 6.November, Part II.

Mona Osman, H. M. Yakout, H. F. Motawe2 and W. F. Ezz El-Arab (2010) productive, physiological, immunological and economical effects of supplementing natural feed additives 
to broiler diets. Egypt. Poult. Sci. Vol (30) (I): (25-53).

Motlagh AM, Babapour V, Pirsaraei ZA, Sheikhi N (2015) Effect of thyme (Zataria Multiflora) extract and probiotic (broilact) feeding on blood thyroid hormones concentration and growth hormone gene expression of liver in broiler chickens. Indian Journal of Fundamental and Applied Life Sciences ISSN: 2231-6345 (Online) An Open Access, Online International Journal Available at www.cibtech.org/sp.ed/jls/2015/01/jls.htm Vol.5 (S1), pp. 1979-1985/Ali et al

Mellor S (2000a) Antibiotics are not the only growth promoters. World Poult 16(1): 14-15

Mellor S (2000b) Nutraceuticals-alternatives to antibiotics. World Poult 16(2): 30-33

NRC (1994) National research council. Nutrient requirements of poultry. 9th ed. National Academy Press, Washington, USA

Offord EA, Guillot F, Aeschbach R, Lo“ liger J, Pfeifer AMA (1997) Antioxidant and biological properties of rosemary components: Implications for food and health. Pages 88-96 in: Natural Antioxidants. Chemistry, Health Effects and Applications.F. Shahidi, ed. AOCS Press

Pourmahmoud B, Aghazadeh AM, Sis NM (2016) the effect of thyme extract on growth performance, digestive organ weights and serum lipoproteins of broilers fed wheat-based diet. Italian Journal of Animal ScienceVolume 12: e53

Richheimer SL, Bernart MW, King GA, Kent MC, Bailey DT (1996) Antioxidant activity of lipid-soluble phenolic diterpenes from rosemary. J. AOCS 73: 507-514

Sadeghi GH, Karimi A, Jahromi SP, Aziz T, Daneshmand A (2011) Effect of cinnamon, thyme and turmeric infusions on the performance and immune response in of 1 to 21 day-old male broilers. Brazilian Journal of
Poultry $\quad$ Science. $\quad$ 14(1): 20.http://www.scielo.br/scielo.php?pid=S1516 $-35 X 2012000100003 \&$ script $=$ sci arttext

Saleh N, Allam T, Abd El-latif A, Ghazy E (2014) The Effects of Dietary Supplementation of Different Levels of Thyme (Thymus vulgaris) and Ginger (Zingiber officinale) Essential Oils on Performance, Hematological, Biochemical and Immunological Parameters of Broiler Chickens. Global Veterinaria 12(6): 736-744

SAS Institute (2004) SAS System for Windows. Version 9.1.2, SAS Institute Inc., Cary, NC, USA.

Soltan MA, Shewita RS, El-Katcha MI (2008) Effect of dietary anise seeds supplementation on growth performance, immune response, carcass traits and some blood parameters of broiler chickens. Int. J. Poult. Sci 7: 10781088.

Soltani M, Tabeidian SA, Ghalamkari G, Adeljoo AH, Mohammadrezaei M, Fosoul SSA (2016) Effect of dietary extract and dried areal parts of Rosmarinus officinalis on performance, immune responses and total serum antioxidant activity in broiler chicks. Asian Pac J Trop Dis6(3): 218-222

Souri H., Khatibjoo A., Taherpoor K., HassanAbadi A., Fattahnia F., Askari M. (2015) Effect of Thymus vulgaris and Satureja khuzestanica Ethanolic Extracts on Broiler Chickens ${ }^{\text {ee }}$ Performance and Immune Response. Iranian Journal of Applied Animal Science 5(2): 437446

Tucker LA (2002b) Plant extracts to maintain poultry performance. Feed Int 23(9): 26-29.

Zeweil H, Ahmed M, Eid Y, Dosoky WM, Abd ElSalam D (2015) effect of vitamin e and phytogenic feed additives on performance, blood constituents and antioxidative properties of broiler chicks. ISSN: 1110-5623 (Print)2090-0570

(On

line) 
تاثير مستويات مختلفة من النباتات الطبية على بعض صفات الانتاجية والفسلجية في فروج اللحم عليم بع

الخلاصة

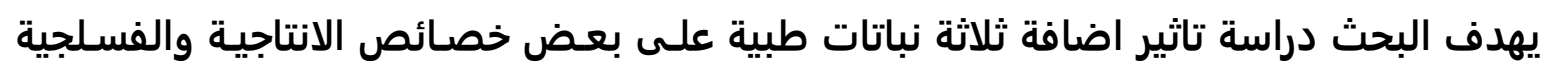

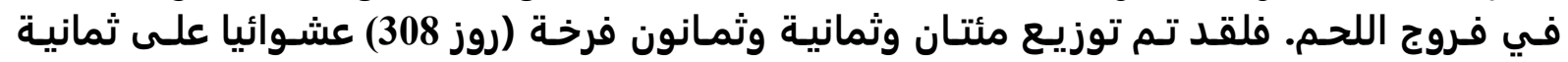

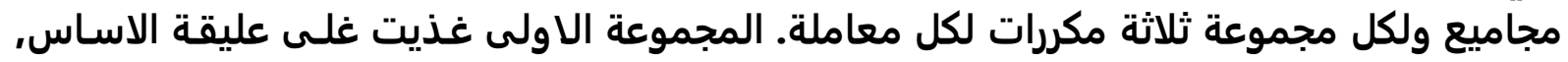

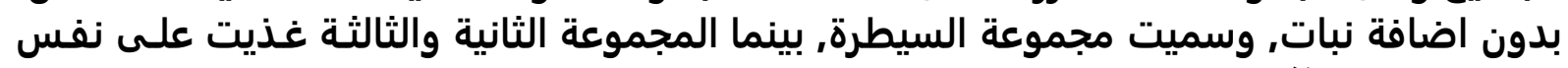

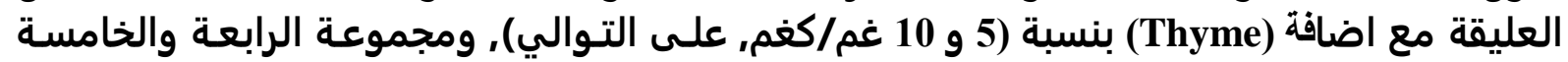

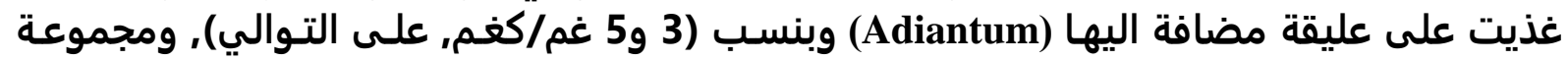

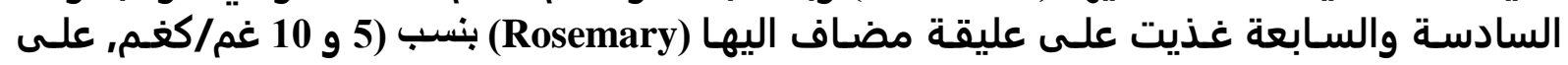

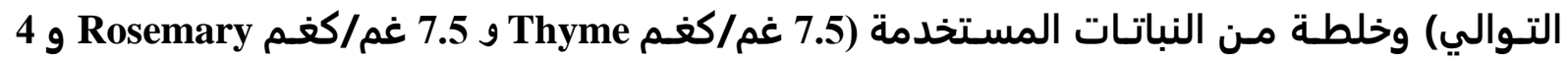

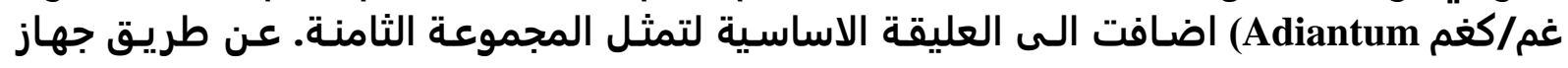
وزن Gas Chromatography/Mass Spectrometry.

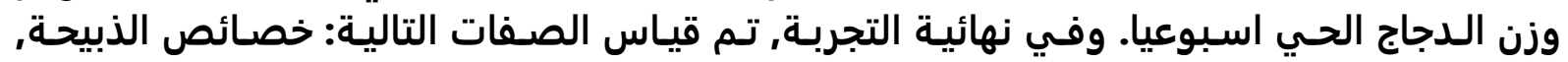

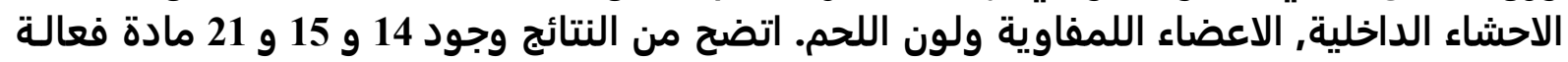

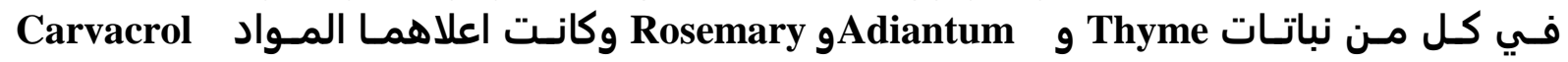

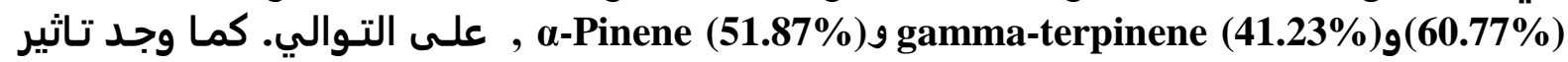

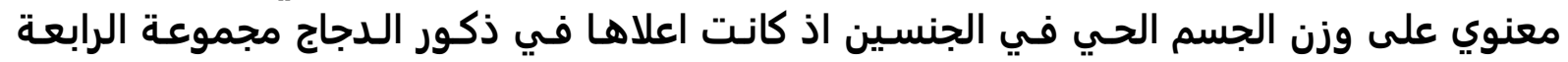

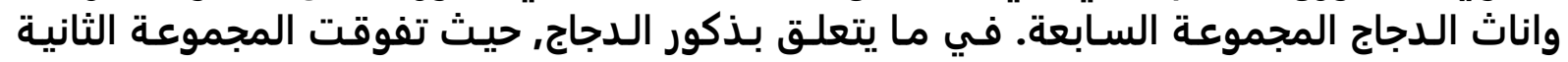

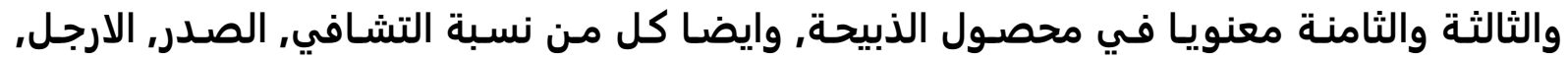

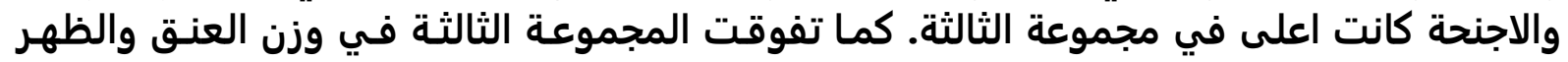

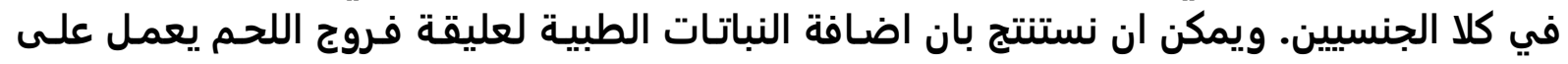

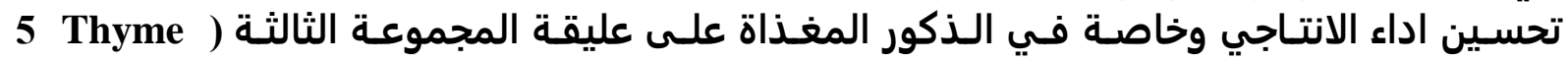
غم/كغم). الكلمات المفتاحية: Rosemary ,Thyme, Adiantum, اداء الانتاجي, الفسلجة, لون اللحم, فروج اللحم. 